\title{
Introduction \\ Ships among ports: Futures of Europe
}

"The inevitable is seldom what anybody expected."

-Barrington Moore ${ }^{1}$

The future is evitable. That is to say if, as many of the contributors to Futures over the years have claimed, there is more than one future possible, and that more than one will be experienced, then talking about 'inevitability' is simply wrong. And what a task it is to attempt to say anything warranted, but nevertheless fresh concerning the futures of Europe-especially in such a context as considering the plural conception of futures in the title of this publication! Immediately after the member states of the Union failed to agree the draft treaty on European Constitution at the Intergovernmental Conference ending on December 13, 2003, the Frankfurter Allgemeine Zeitung provided two full pages of political coverage under the rubric "After the Failure [or 'running aground'] of BrusselsThe EU in Crisis", and on the front page reported "The EU at an Uncertain Future" [2]. Six months later, on the day after those same states agreed a Treaty Establishing a Constitution for Europe, The Irish Times reported that Sweden still supported the EU, but not the Euro, and that EU Council President Bertie Ahearn, the Irish Prime Minister, thanked all those who helped with 'a ship that has been safely docked today' [5]. Ships are useful not when they remain in port, but rather when they move, so six months later, after nearly four decades of failed attempts, on December 17, 2004, Turkey was given the possibility of opening talks for accession to the European Union. From the European docks of Ireland, Germany, Sweden, and the UK, there are contributions in this special edition of Futures on "The Futures of Europe". Even within the geographic limits of Europe, the ships come at different speeds, as represented by two authors from outside the Eurozone and four within. There are also contributions from a ship between ports in Italy and the USA and from a ship between Germany and Turkey. And there is something from that port across the ocean-the USA.

What may be perhaps the most telling contribution to this volume, however, is the one that is not here. I had invited a colleague from Beijing to provide a prospective from China on the futures of Europe, and he had enthusiastically accepted. But as he

\footnotetext{
${ }^{1}$ As quoted in Theodore M. Lowi, American Government: Incomplete Conquest (1973) p. 691. 
began to write, he contacted me to say that he did not think that he could say anything definitive until the outcome of the Treaty Establishing the Constitution for Europe was known for certain. At first, he said this meaning only that he would be delayed. After a while, it became obvious to him that he had set impossibility before himself. And so must we all proceed in talking about the futures of Europe without a completed project to analyze, but rather an ever-changing society. Try though we must to make hay while the sun still shines.

A few years back, having been unsurprisingly saturated with discussions of 'Europe' that treated the word as a legal concept only while discussing the topic of the future of Europe in a conference largely attended and presented by lawyers, I suggested that the future of Europe, even the future of Europe in its legal sense or the future of the law in Europe, must be considered in the context of other disciplines and other ways of thinking and being [3]. The tide against this sentiment is strong, however, and the inevitable futurists are not only narrow in their vision of the futures of Europe as being a question of legal institutions [1], but of electronic legal institutions, as announced by The Europa Newsletter, 24 March 2005, Issue 53, wherein it is explained why 'eGovernment is the future for Europe'. This present edition was thus intended to be an opportunity to consider scholarship on the futures of Europe from both within and outside of Europe, and from within and outside of the law. The final product gestures in this direction, and also provides some of the positions from within legal study from which room for further expansion is possible.

Of course, even the legal nature of the futures of Europe, as structured through treaties, requires more than signatures at summits-it requires nations to ratify and adopt the treaty as domestic law at home. With that in mind, The Economist took the euro-skeptic position suggesting through a football analogy that the citizens of the member states ought to give the treaty the red card if and when they had the opportunity to do so through their home state's referendum [4]. Perhaps just as predictably, The Economist's dismissal was framed in the notion of Europe as a legal entity. The arguments put forward by The Economist, and the weaknesses of the treaty to which it referred, are all failures in public law, if they are failures at all. Not mentioned are any of the cultural, symbolic or, ironically, even economic failures or successes that the treaty could mean.

This issue of Futures begins with authors who consider perspectives in addition to, and outside of, the legal framework of the futures of Europe. Alessandra Beasley, a native of Italy, working in the United States, addresses the rhetorical dimensions of European Union citizenship as she focuses on public discourse as constitutive of new models of political participation and engagement. Tracing the idea of citizenship in the writings of Hannah Arendt, Immanuel Kant, and Giambattista Vico, Beasley maintains that discourse and imagination become necessary for a new dimension of European Union citizenship. Michael Cronin and Margot Horspool provide bookends of translation studies to the collection. Dublin's Cronin makes the case for defining Europe culturally, rather than legally or politically, echoing Jacques Delors' sentiment that "You don't fall in love with a common market: you need something else".

As perhaps the most resonant example of how one defines a culture, that is, through language, Margot Horspool offers a variety of combinations-Dutch and British, linguist and lawyer. Having been a translator for the EU, she punctuates her insights with 
the practical examples that only one on the inside could have available, and at the same time uses those examples to inform her legal scholarship. Horspool's work also provides a practical and theoretically astute bridge between, on one hand, the spoken and written natural languages of Europe, and, on the other hand, the legal institutions of an expanding Europe. Stephan Hobe and Stefan Haack, from the two sides of the formerly divided Germany clearly outline where the legal institution ship has been, where it is now, and perhaps most importantly to combat superstate alarmists, where it is not now. Hobe traces the legal history of the European Union from British Prime Minister Winston Churchill's thought of a post-war 'United States of Europe', with the explicit purpose of preventing war, through its broadest integration through economic measures, to its present social and political integration. As Haack notes, the pouvoir constituant is also a perhaps idiomatic phrase from the language of one of the founding EU states that, like Verfassung, helps us to understand what it means to constitute.

Elif Ücer notes well that perhaps one of the largest remaining factors that truly separates Turkey from the rest of Europe is the comportment of its citizens toward the law. She offers her own experiences and those of her family as a case study in the presence of Turkey already in the EU. Anna Fernqvist makes the case that different countries take time to adapt to (or reject) a wider Europe, and hence their relationship to the futures of Europe at 'different speeds'. In this story is an interesting paradox, that the so called 'open' society of Sweden is in fact a 'closed' society, and is only 'open' within its own tightly drawn cultural boundaries.

Much of the debate about European currency and expansion gravitates toward the ancient trope of definition. While few look to the connection to the goddess Europa, many look at the wide range of defining factors, beginning with the relatively easy material ones like geology, and then moving to the other end of the spectrum, toward symbol, through physiology, race, geography, language, and religion. What is not often discussed in this context, however, is the cultural marker of a society's relationship to its legal order.

In my own contribution, I continue my infrequent, but regular Futures series of essays that find their reason neither in the material world nor in the cultural world of referents, but in the symbol itself; here, the word 'constitution'. I suggest that one can understand even communities known mostly through legal institutions as cultural communities, and that the constitution of the legal communities is accomplished through the constitution of the community on the whole, which is accomplished largely through language. The internal structure of my argument is then in fact the external structure of the order in which the articles are arranged.

I would like to thank Futures editor Ziauddin Sardar for his support in producing this issue, despite the annoying delays that editors expect, but quixotically hope do not come to pass, and the Futures referee team for constructive guidance. I would also like to thank Matthew Roy of Duquesne University, Jan Wetzel, Jörn Griebel, D.E.S., of the Law Centre for European and International Cooperation, Cologne, Germany (R.I.Z.) for their translation skills, juridical expertise and abilities to resurrect lost texts, and Andrea End, also of the R.I.Z. for her research and bibliographic work. If this special edition in any way fails to be special, the failure lies with me, and certainly not with any of them. 


\section{References}

[1] Europa, 'The Future of the European Union' website: http://europa.eu.int/constitution/futurum/index_en.htm

[2] Frankfurter Allgemeine Zeitung, 15 December 2003, Nr. 291.

[3] K. Junker, Constituting the future of Europe through a democracy of disciplines in: R. Herzog, S. Hobe (Eds.), Die Europäische Union auf dem Weg zum verfassten Staatenverbund: Prespektiven der europäischen Verfassungsordnung, C.H. Beck, Munich, 2004, pp. 184-196.

[4] 'The Right Verdict', opinion, The Economist, June 26th-July 2nd, 2004, p. 13.

[5] D. Staunton, Deaglán De Bréadún, EU enters new era with deal on historic accord, Irish Times 47033 (2004) 1 .

Kirk W. Junker

Duquesne University School of Law, 600 Locust Street, Pittsburgh, PA 15282, USA

E-mail address: junker@duq.edu

Available online 10 August 2005 